\title{
Case Report \\ Prenatal Diagnosis of Congenital Mesenchymal Hamartoma of Liver: A Case Report
}

\author{
Sreelakshmi Kodandapani, ${ }^{1}$ Muralidhar V. Pai, ${ }^{1}$ Vijay Kumar, ${ }^{2}$ and Kanthilatha V. Pai ${ }^{3}$ \\ ${ }^{1}$ Department of OBG, Kasturba Medical College, Manipal University, Manipal 576104, India \\ ${ }^{2}$ Department of Pediatric Surgery, Kasturba Medical College, Manipal 576104, India \\ ${ }^{3}$ Department of Pathology, Kasturba Medical College, Manipal 576104, India
}

Correspondence should be addressed to Sreelakshmi Kodandapani, laxmivinayaka@gmail.com

Received 1 June 2011; Accepted 27 June 2011

Academic Editors: H.-C. Lai and E. C. Nwosu

Copyright (C) 2011 Sreelakshmi Kodandapani et al. This is an open access article distributed under the Creative Commons Attribution License, which permits unrestricted use, distribution, and reproduction in any medium, provided the original work is properly cited.

Hepatic mesenchymal hamartoma is a rare benign tumor. We present an unusual case of a fetal abdominal cyst, later diagnosed histopathologically to be mesenchymal hamartoma of liver. The organ of origin was indeterminate on both prenatal and postnatal ultrasounds. As there are no specific sonological findings, whenever a large multicystic fetal abdominal cyst is seen, mesenchymal hamartoma should be considered as a possibility.

\section{Introduction}

Increase use of antenatal ultrasound has resulted in greater incidence of prenatal diagnosis of congenital malformations. Many anomalies which manifest in the third trimester are diagnosed, as serial growth of fetus is monitored by ultrasound. Fetal abdominal cyst with normal kidneys and liquor in the third trimester is probably ovarian cyst, mesenteric cyst, or rarely mesenchymal hamartoma of liver as reported in this case. Mesenchymal hamartoma is a cystic benign tumor, but rapid growth to enormous size can lead to fetal hydrops and demise. Case report with management and review of the literature of congenital mesenchymal hamartoma of liver is presented.

\section{Case Report}

A 25-year-old primigravida was referred to us at 38 weeks for management of cardiac disease complicating pregnancy. Incidentally, during antenatal ultrasound, an intra-abdominal anechoic cyst, just above the level of kidneys, measuring $7 \times 8 \mathrm{~cm}$ was noted (Figure 1). Bladder was visualized separately. Placenta was situated in the upper segment and amniotic fluid index was normal. Intra-abdominal organs, heart, and diaphragm were not displaced. Estimated fetal weight was $2.3 \mathrm{~kg}$ suggesting mild IUGR. Provisional diagnosis of either mesenteric, ovarian, or duplication cyst was considered. She had mitral valve prolapse with NYHA class I. Since cyst was neither compressing other organs nor distending abdomen, vaginal delivery was planned. However, cesarean delivery was done for fetal distress. A female baby of $2.15 \mathrm{~kg}$, with APGAR 9 and 10 at 1 and 5 minutes, respectively, was delivered. Postnatal examination of the baby revealed a palpable cystic mass of $10 \times 8 \mathrm{~cm}$ in the right hypochondrium. No other congenital abnormalities were noted. Baby tolerated feeds well. Ultrasound was suggestive of an anechoic cyst in close relation to the left lobe of liver. Conservative management was advised by pediatric surgeon. Baby was on regular followup.

However, laparotomy was performed at 2 months for persistence of cyst. Liver function, renal function tests, and electrolytes were preoperatively normal. At laparotomy, a cystic lesion arising from 5th segment of liver was noted and the same was excised (Figure 2). Histopathology revealed that the cyst was devoid of lining epithelium and was lined by hyalinized fibrous tissue suggestive of mesenchymal hamartoma of liver (Figure 3).

Postoperative period was uneventful. After 2 months of surgery, a small cystic lesion $(4 \times 1 \mathrm{~cm})$ was seen arising from the inferior part of right lobe of liver. It was decided to 
TABLE 1: Congenital mesenchymal hamartoma of liver: presentation and management.

\begin{tabular}{|c|c|c|c|c|c|}
\hline $\begin{array}{l}\text { Author, year, } \\
\text { number of cases } \\
(n)\end{array}$ & $\begin{array}{l}\text { Gestational } \\
\text { age (weeks) }\end{array}$ & $\begin{array}{l}\text { Presentation/mode of } \\
\text { delivery }\end{array}$ & Management & Post-op course followup & Tumour size \\
\hline $\begin{array}{l}\text { Kamata et al. [1] } \\
2003 n=1\end{array}$ & 30 & $\begin{array}{l}\text { Rapidly growing cyst with } \\
\text { maternal hypertension, } \\
\text { anemia, preterm labor. } \\
\text { Cesarean delivery }\end{array}$ & Surgical resection & $\begin{array}{l}\text { 3-year followup: alive } \\
\text { and healthy }\end{array}$ & $7 \times 6 \times 5 \mathrm{~cm}$ \\
\hline $\begin{array}{l}\text { Bartho et al. [2] } \\
1992 n=1\end{array}$ & 31 & $\begin{array}{l}\text { Abdominal cyst. } \\
\text { Cesarean delivery }\end{array}$ & Hepato lobectomy & NA & $7 \times 4 \mathrm{~cm}$ \\
\hline $\begin{array}{l}\text { Tovbin et al. [3] } \\
1997 n=1\end{array}$ & 29 & $\begin{array}{l}\text { Abdominal cyst. } \\
\text { Vaginal delivery }\end{array}$ & Surgical excision & 15 th postnatal day & $10 \times 8 \mathrm{~cm}$ \\
\hline $\begin{array}{l}\text { Dickinson et al. [4] } \\
1999 n=1\end{array}$ & 26 & $\begin{array}{l}\text { Progressing abdominal } \\
\text { mass fetal hydrops, fetal } \\
\text { demise. Vaginal delivery }\end{array}$ & Nil & Nil & $8 \times 7 \times 6 \mathrm{~cm}$ \\
\hline $\begin{array}{l}\text { Tsao et al. [5] } 2002 \\
n=2\end{array}$ & Fetus 1: 35 & $\begin{array}{l}\text { Fetus 1: rapidly growing } \\
\text { mass, vaginal delivery. } \\
\text { Fetus 2: rapidly progressing } \\
\text { mass, fetal hydrops }\end{array}$ & $\begin{array}{l}\text { Fetus 1: } \\
\text { antenatalaspiration } \\
\text { postnatal laparoscopic } \\
\text { excision of cyst. } \\
\text { Fetus 2: excision, } \\
\text { neonatal death }\end{array}$ & $\begin{array}{l}\text { Fetus 1: two-week } \\
\text { postoperative period was } \\
\text { normal } \\
\text { Fetus 2: autopsy showed } \\
\text { hamartoma umbilical } \\
\text { vein compression }\end{array}$ & $\begin{array}{l}\text { Fetus 1: } \\
9 \times 6 \mathrm{~cm} \\
\text { Fetus } 2: \\
13 \times 13 \times 7 \mathrm{~cm} \\
\text { weighed } \\
635 \mathrm{~g}\end{array}$ \\
\hline $\begin{array}{l}\text { Laberge et al. [6] } \\
2005 n=1\end{array}$ & 23 & $\begin{array}{l}\text { Abdominal cyst } \\
\text { polyhydramnios, fetal } \\
\text { hydrops, fetal demise }\end{array}$ & Nil & $\begin{array}{l}\text { Placental villous } \\
\text { hyperplasia }\end{array}$ & \\
\hline
\end{tabular}

NA: not available.

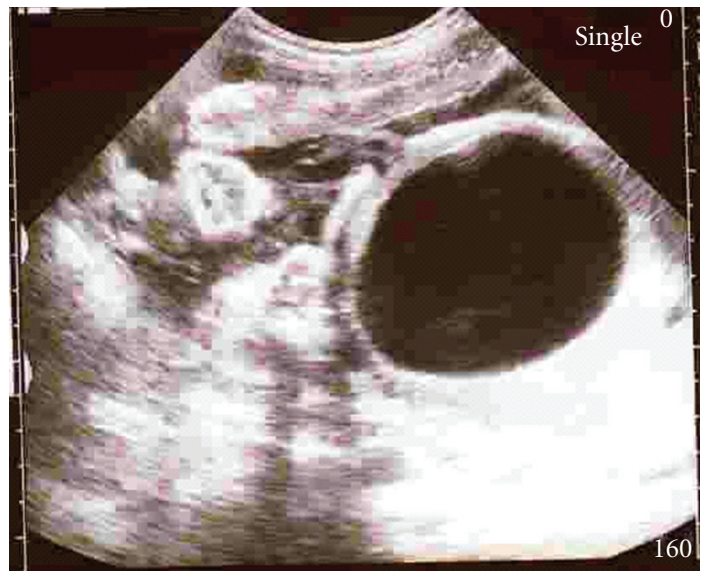

FIgURe 1: Prenatal ultrasound picture showing intra-abdominal cyst measuring $8 \times 8 \mathrm{~cm}$.

followup, the cyst. At the end of 2 months of postoperative follow up the cystic lesion reduced in size to $5 \mathrm{~mm}$ and baby was asymptomatic with good catch up growth.

\section{Discussion}

Hepatic tumors are rare and comprise of $5 \%$ of the total neoplasms in fetal and neonatal period [7]. After hemangiomas, mesenchymal hamartomas are the second most common hepatic tumours in childhood [8]. Hepatic mesenchymal hamartoma is a benign tumor, defined as an excessive focal overgrowth of mature normal cells and stroma native

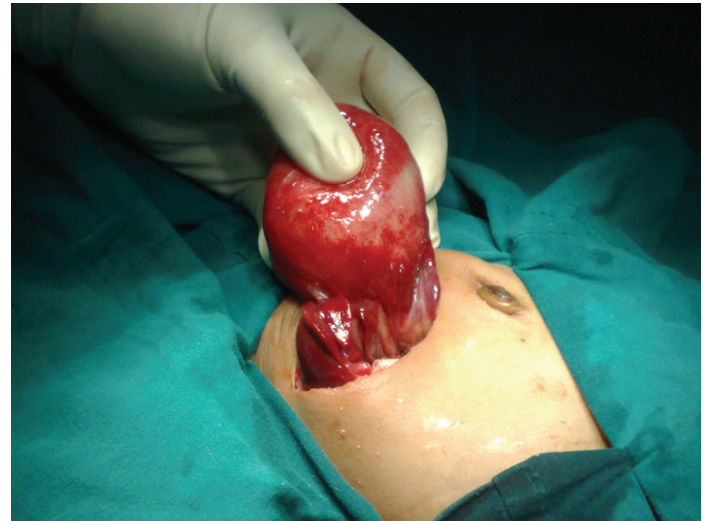

FIGURE 2: Intraoperative picture showing cyst arising from liver.

to the liver. Hamartomas are devoid of lining epithelium with hemorrhage and necrosis. They are well circumscribed and are away from the biliary ducts. Liver architecture and function is well maintained. With the advent of high resolution ultrasound, these can be detected prenatally as intra-abdominal cysts of unknown origin. Typically, hamartomas of liver are not associated with any anomalies, but associations with congenital heart disease, gut malrotation, omphalocele, myelomeningocele, and biliary atresia have been reported [9]. Prognostic factors are period of gestation of presentation, tumor size, rate of growth, and associated anomalies.

In the largest series by Isaacs Jr, 45 cases of mesenchymal tumors are reported over a period of 35 years (1970-2005) [10]. A total of 14 cases were antenatally diagnosed in this 


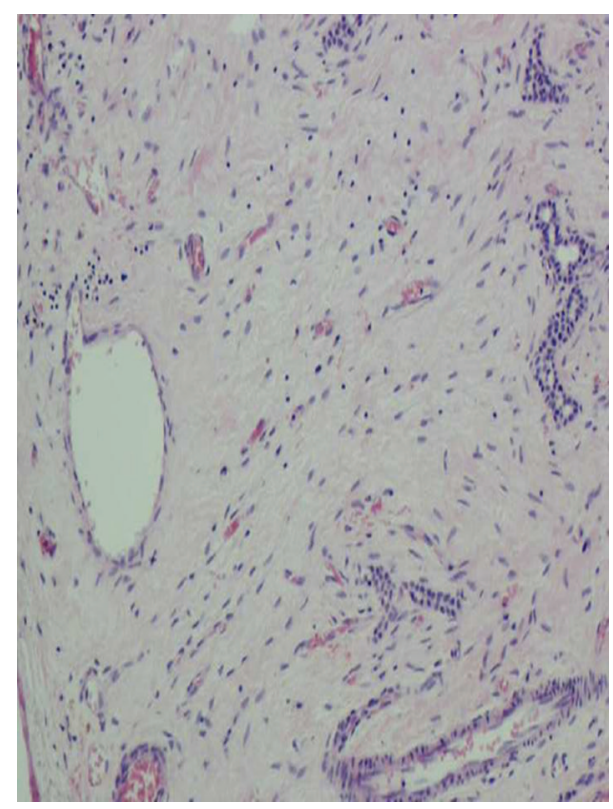

FIGURE 3: Histopathological image with fluid-filled lakes and devoid of epithelium.

series and most common presentation was abdominal cyst with a mean gestational age of 35 weeks (15-40). While $64 \%$ underwent surgical resection, only 10 untreated survived. Most common cause of death was rapidly progressive tumor with respiratory distress. Overall survival was $64 \%$ in this series [10]. Slow growth and late onset presentation of cyst in our case was a favorable factor.

Early onset of presentation, rapidly progressing tumor, and polyhydramnios compression of arteries are poor prognostic factors which were seen in cases reported by Dickinson et al., Tsao et al., and Laberge et al. [4-6] (Table 1). Thus, these patients should be on regular followup. Rapidly growing tumor may require antenatal aspiration of cyst as was performed in one of the cases reported by Tsao et al. [5].

Cesarean delivery is not per se indicated unless it is a big tumor anticipating abdominal dystocia as can be inferred from Table 1. Recurrence and malignant transformation is rarely observed, hence, warrants careful follow up [11]. Our case has been followedup for 6 months at the time of reporting and has appropriate growth and neurodevelopment.

\section{References}

[1] S. Kamata, K. Nose, T. Sawai et al., "Fetal mesenchymal hamartoma of the liver: report of a case," Journal of Pediatric Surgery, vol. 38, no. 4, pp. 639-641, 2003.

[2] S. Bartho, H. J. Schulz, R. Bollmann, and U. Specht, "Prenatally diagnosed mesenchymal hamartoma of the liver," Zentralblatt fur Pathologie, vol. 138, no. 2, pp. 141-144, 1992.

[3] J. Tovbin, M. Segal, I. Tavori, G. Lotan, and R. Maymon, "Hepatic mesenchymal hamartoma: a pediatric tumor that may be diagnosed prenatally," Ultrasound in Obstetrics and Gynecology, vol. 10, no. 1, pp. 63-65, 1997.

[4] J. E. Dickinson, S. Knowles, and J. M. Phillips, "Prenatal diagnosis of hepatic mesenchymal hamartoma," Prenatal Diagnosis, vol. 19, no. 1, pp. 81-84, 1999.
[5] K. Tsao, S. Hirose, R. Sydorak et al., "Fetal therapy for giant hepatic cysts," Journal of Pediatric Surgery, vol. 37, no. 10, pp. E31-E34, 2002.

[6] J. M. Laberge, Y. Patenaude, V. Desilets et al., "Large hepatic mesenchymal hamartoma leading to mid-trimester fetal demise," Fetal Diagnosis and Therapy, vol. 20, no. 2, pp. 141$145,2005$.

[7] L. P. Dehner, "Hepatic tumors in the pediatric age group: a distinctive clinicopathologic spectrum," Perspectives in Pediatric Pathology, vol. 4, pp. 217-268, 1978.

[8] J. T. Stocker and K. G. Ishak, "Mesenchymal hamartoma of the liver: report of 30 cases and review of the literature," Pediatric Pathology, vol. 1, no. 3, pp. 245-267, 1983.

[9] M. D. Stringer and N. K. Alizai, "Mesenchymal hamartoma of the liver: a systematic review," Journal of Pediatric Surgery, vol. 40, no. 11, pp. 1681-1690, 2005.

[10] H. Isaacs, "Fetal and neonatal hepatic tumors," Journal of Pediatric Surgery, vol. 42, no. 11, pp. 1797-1803, 2007.

[11] T. M. Ramanujam, J. C. Ramesh, D. W. Goh et al., "Malignant transformation of mesenchymal hamartoma of the liver: case report and review of the literature," Journal of Pediatric Surgery, vol. 34, no. 11, pp. 1684-1686, 1999. 


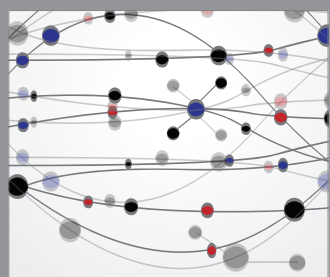

The Scientific World Journal
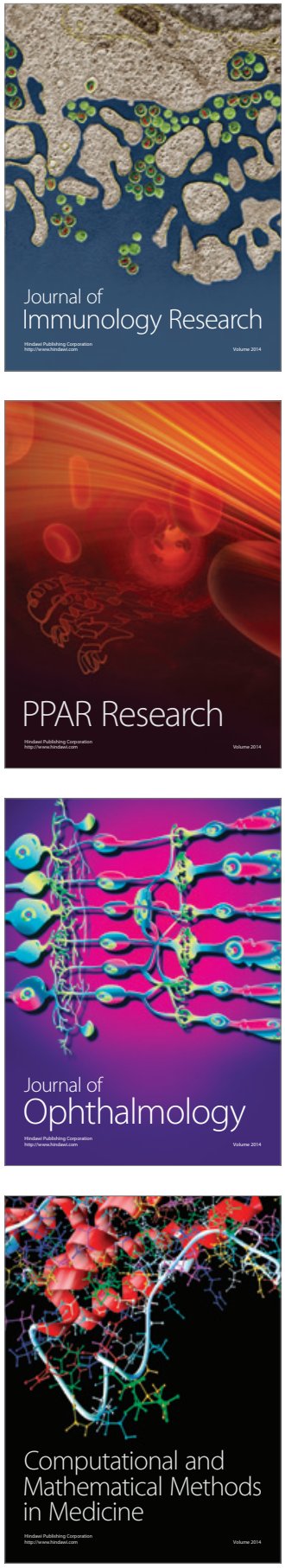

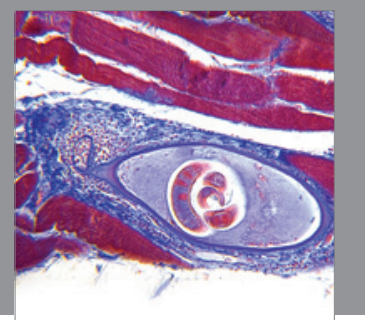

Gastroenterology

Research and Practice
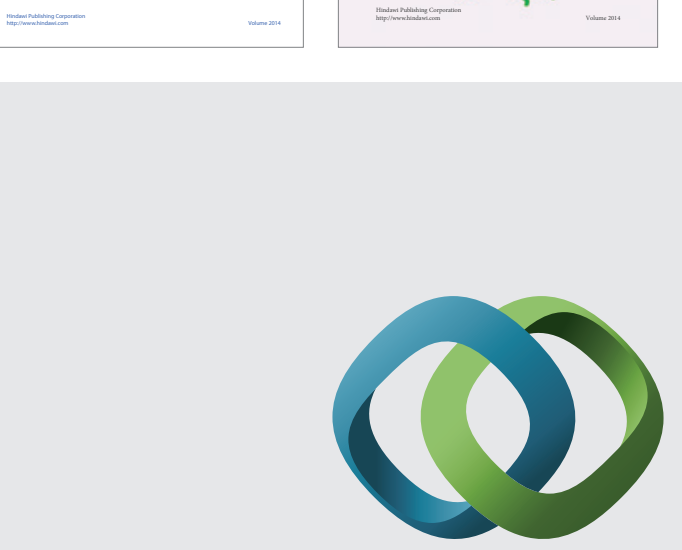

\section{Hindawi}

Submit your manuscripts at

http://www.hindawi.com
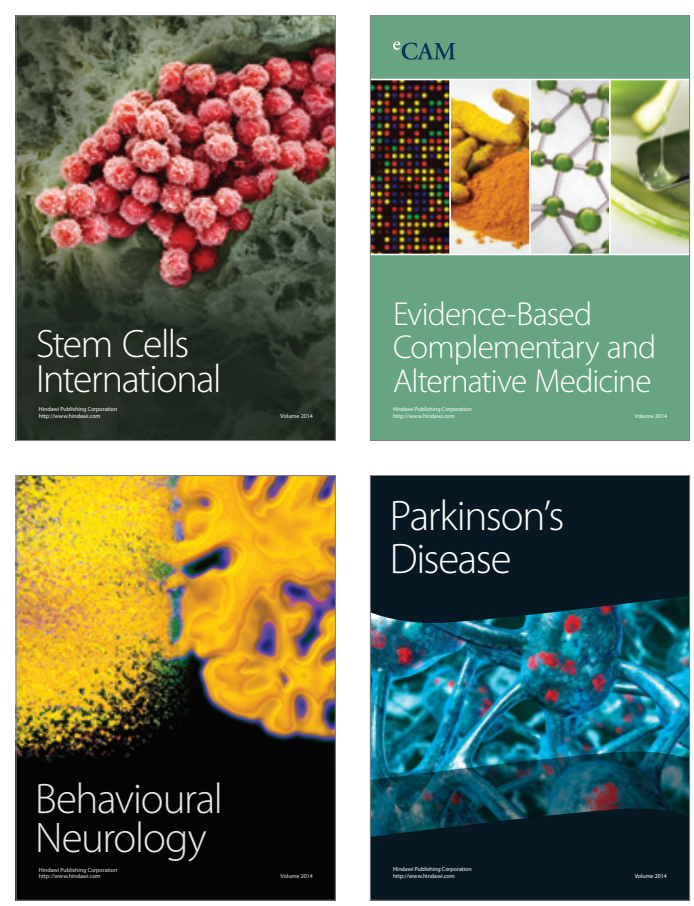

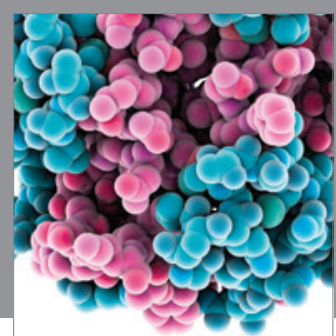

Journal of
Diabetes Research

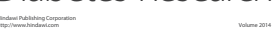

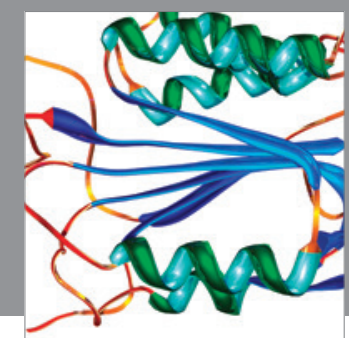

Disease Markers
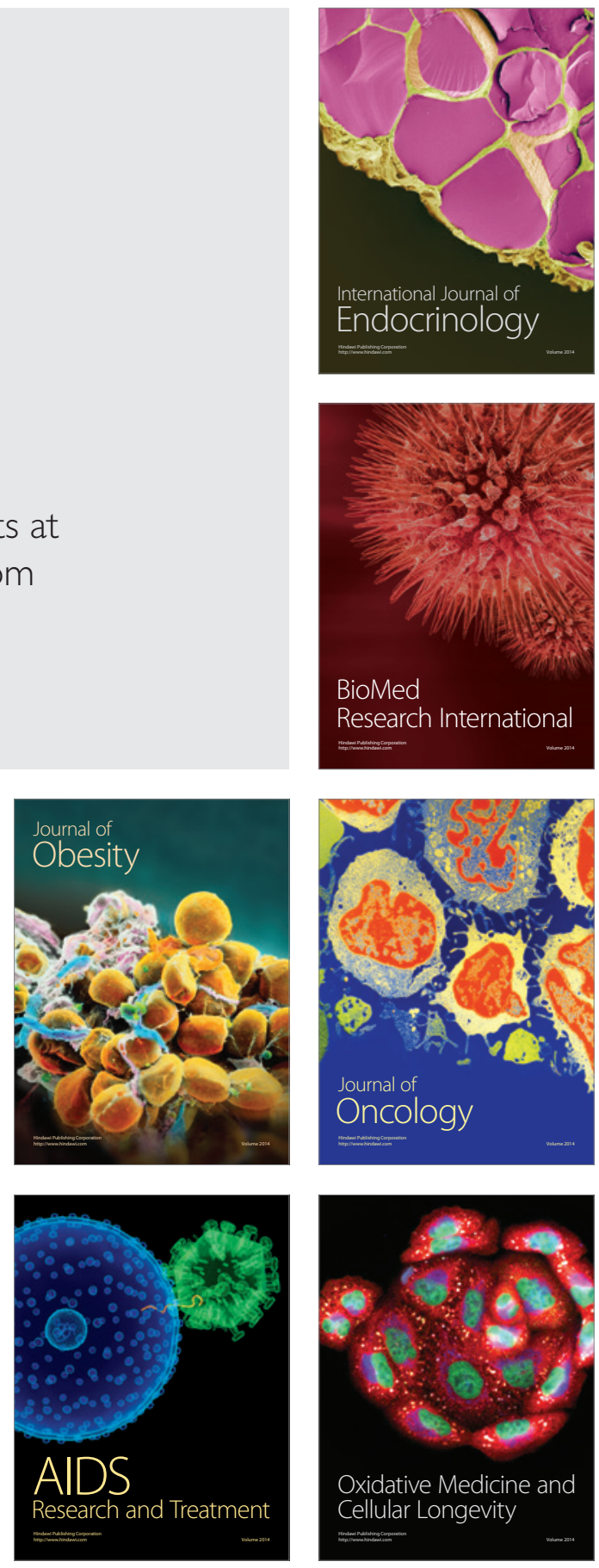